\title{
MEDIA KOMIK PAPERTOON DALAM MENUMBUHKAN MINAT MEMBACA PADA ANAK KELOMPOK B DI TAMAN KANAK-KANAK
}

\author{
Mutiara Nova Agustin ${ }^{1}$, Yasbiati $^{2}$, Sumardi $^{3}$ \\ ${ }^{1}$ Program Studi S1 PGPAUD UPI Kampus Tasikmalaya \\ ${ }^{2}$ Program Studi S1 PGPAUD UPI Kampus Tasikmalaya \\ ${ }^{3}$ Program Studi S1 PGPAUD UPI Kampus Tasikmalaya
}

Email: yasbiati@upi.edu

(Received: Nopember 2019; Accepted: Nopember 2019; Published: Desember 2019)

\begin{abstract}
Growing interest in reading before children are taught to read is something that is often ignored but actually is the most appropriate solution. Forcing or even threatening children to want to read later will instead foster reluctance and even laziness in children to read. The solution that researchers present in this study is by developing a media in the form of papertoon comics designed to foster children's interest in reading. This research was conducted using the Design Based Research (DBR) method by referring to the model proposed by Reveers. If described briefly, the stages in this study consist of: (1) analyzing the problem; (2) developing a design that is making media and conducting product validation for experts; (3) evaluation of the feasibility of repeated trials; (4) reflection and revision so that the product is feasible to be distributed. Teachers and children of the Kindergarten B group became participants in this study. Meanwhile, for data collection, what is used is interviews, validation of several experts, and observation of behavior displayed by children when the product is tested. The conclusion obtained after the trial also showed positive results in the second stage. In general, despite all the limitations, the product is declared feasible to use and influences the child's reading interest based on the teacher's responses and observations of the child's treatment.
\end{abstract}

Keywords: interest in reading, tools of earning, komik papertoon comic

\begin{abstract}
Abstrak
Menumbuhkan minat membaca sebelum anak diajarkan membaca menjadi hal yang kerapkali di abaikan namun sesunggunya merupakan solusi paling tepat. Memaksa atau bahkan mengancam anak agar mau membaca nantinya malah akan menumbuhkan keengganan bahkan kemalasan pada diri anak untuk membaca. Solusi yang peneliti sajikan dalam penelitian ini yakni dengan mengembangkan sebuah media berupa komik papertoon yang dirancang guna menumbuhkan minat anak dalam membaca. Penelitian ini dilaksanakan menggunakan metode Design Based Research (DBR) dengan mengacu pada model yang dikemukakan oleeh Reveers. Apabila diuraikan secara singkat, tahapan dalam penelitian ini terdiri dari: (1) melakukan analisis permasalahan; (2) mengembangkan desain yakni pembuatan media serta melakukan validasi produk pada ahli; (3) evaluasi uji coba kelayakan yang dilakukan secara berulang; (4) refleksi dan revisi agar produk layak disebar. Guru dan anak kelompok B Taman Kanak-kanak menjadi partisipan dalam penelitian ini. Sedangkan, untuk pengumpulan data, yang digunakan adalah wawancara, validasi beberapa ahli, serta observasi prilaku yang ditampilkan anak saat produk diuji cobakan. Implementasi produk dilakukan di dua kelas yakni kelas B1 dan kelas B2 TK Perwari 1. Rancangan produk dinyatakan layak oleh validator ahli dalam beberapa kali revisi. Secara umum, meski dengan segala keterbatasan, produk dinyatakan layak digunakan dan memberi pengaruh terhadap minat membaca anak berdasarkan tanggapan guru dan hasil observasi perlakuan anak.
\end{abstract}

Kata Kunci: minat membaca, media pembelajaran, komik papertoon 


\section{PENDAHULUAN}

Mendapatkan pengetahuan baru, meningkatkan daya pikir dan daya imajinasi, menjadikan masyarakat kritis, informatif dan kreatif, merupakan sebagian kecil manfaat dari membaca. bahkan dalam satu kesempatan, mohammad hatta pernah berujar "Aku rela dipenjara asalkan bersama buku, karena dengan buku aku bebas"(dalam) hal ini mengindikasikan bahwa membaca, merupakan suatu jendela yang menghantarkan seseorang kehadapan dunia bahkan hingga keinti-intinya. Kemampuan membaca seseorang jelas sangat penting apalagi dalam segi pendidikan.

Sebagai negara yang memiliki misi besar untuk mencapai abad emas di tahun 2045, tentunya membaca menjadi sesuatu yang perlu diperhitungkan. Sebagaimana diketahui, buku adalah gudang ilmu dan membaca, berperan sebagai kuncinya. Bukan hal mengherankan jika indonesia menjadi negara bermasyarakat yang berpengetahuan minim bila peringkat minat membacanya saja berada diurutan ke 60 dari 61 negara (dalam Widianto, 2017). Permasalahan ini tentu berakar dari kebiasaan masyarakat Indonesia yang kurang diperkenalkan pada budaya membaca. Jika saja semenjak dini masyarakat Indonesia dilatih untuk mencintai buku dan menyenangi membaca, tentu hingga dewasa pun kebiasaan tersebut akan selalu tertanam dan anggapan bahwa membaca merupakan suatu kebutuhan, mutlak akan selalu membayangi.

Permasalahan ini tergambarkan pula dalam pembelajaran membaca yang berlangsung di salah-satu taman kanak-kanak yang berlokasi di kota Tasikmalaya. Bukannya anak distimulus dan dilatih untuk menyukai bahan bacaan, anak malah cenderung diajarkan membaca dengan metode konfensional. Sehingga bukan hal mengherankan bila pada akhirnya anak-anak malas sekali membaca karena sedari awal membaca sudah ditanamkan sebagai suatu tugas memberatkan dan membosankan. Mengajarkan anak usia dini membaca tentulah harus dilakukan dengan sesuai dan mengacu pada karakteristiknya. Sebagaimana tertera dalam Undang-Undang No. 20 Tahun 2003 Tentang Sistem Pendidikan Nasional, anak usia dini merupakan anak dengan rentang usia $0-6$ tahun. meski disinyalir memiliki berjuta potensi yang siap dikembangkan, potensi tersebut pun rawan sekali musnah. Dalam bukunya, Hurlock (1978, hlm. 116) mengemukakan bahwa perkembangan minat pada diri seseorang dipengaruhi oleh dua aspek yakni, aspek kognitif dan aspek afektif. Karena dalam penelitian ini peneliti lebih berfokus pada minat membaca anak, yaitu penumbuhan keinginan atau kecendrungan membaca pada diri anak, maka aspek yang akan lebih ditonjolkan dan diuraikan adalah aspek afektif. Hal ini sejalan dengan teori Bloom atau yang lebih dikenal sebagai taksonomi Bloom, yang mengungkapkan bahwa minat merupakan bagian dari afektif yakni, salah-satu karakteristik dari afektif.

Minat membaca yang dikembangkan semenjak usia dini meskipun akan memberikan dampak yang signifikan namun, penerapannya tetaplah harus dilaksanakan dengan cara-cara tertentu. Teknik yang keliru digunakan bukannya akan menumbuhkan minat membaca anak namun malah akan menimbulkan akibat fatal. Sehingga menumbuhkan minat membaca pada usia dini pun harus diupayakan dengan kegiatankegiatan terencana yang sejalan dengan karakteristik anak (dalam Sujiono, 2013, hlm. 84 - 87). Dengan adanya media yang menarik, anak akan belajar tanpa sedikitpun perasaan terpaksa.

Media komik Papertoon merupakan suatu media modifikasi dari komik dan penyederhanaan dari webtoon yang peneliti rancang demi mengembangkan minat membaca pada anak usia dini. Sifatnya yang tidak menekan anak dan dibuat menarik sangat sesuai karakteristik anak usia dini. Selama ini, penggunaan media sejenis komik masih jarang digunakan dalam pembelajaran di taman kanak-kanak. Sehingga penulis berinisiatif untuk memasukan media papertoon ke dalam pembelajaran untuk 
melihat manfaat terhadap perkembangan anak.

Penelitian ini dilakukan dengan maksud dan tujuan untuk: (1) mengetahui penggunaam media pembelajaran yang digunakan untuk menumbuhkan minat membaca anak kelompok B Taman Kanakkanak di kota Tasikmalaya. (2) Menghasilkan sebuah rancangan produk berupa media komik papertoon yang dapat menumbuhkan minat membaca pada anak kelompok B Taman Kanak-kanak. (3) Implementasi media komik papertoon dalam menumbuhkan minat membaca pana anak kelompok B. (4) Refleksi pengembangan media papertoon yang dapat digunakan untuk menumbuhkan minat membaca anak kelompok B.

Dengan dikembangkannya media ini, diharapkan minat membaca yang ditanamkan pada anak kelompok B akan berkembang sesuai harapan. Serta menghasilkan suatu media baru yang memiliki dampak signifikan terhadap meningkatnya minat baca di bangsa indonesia ini.

\section{KAJIAN TEORI}

Mengutip dari Undang-Undang Sistem Pendidikan Nasioanl tahun 2003, anak pada rentang usia antara $0-6$ tahun adalah anak usia dini. Anak pada usia lima tahun pertama mengalami masa peka atau dalam istilah yang diungkapkan Montesori adalah proide sensitif, yakni masa dimana anak telah mencapai kesiapan untuk memulai kegiatan belajar dan mudah menerima stimulus-stimulus dari lingkungan sekitarnya (dalam Sujiono, 2009, hlm. 54). Anak dinilai memiliki berjuta potensi dan berada pada priode sensitif, dimana pada masa ini anak sangat mudah mencerna stimulus-stimulus yang diberikan (dalam Sujiono, 2009, hlm. 54).

Seperti yang diungkapkan oleh Suwardi (dalam Anggraini, 2017, hlm. 3) bahwa penanaman budaya membaca akan sangat sulit bila diterapkan pada orang dewasa. Solusi utama agar gemar membaca dapat dimiliki setiap individu, penumbuhannya harus dioptimalkan semenjak usia dini. Apabila dilihat dari akar katanya, Syah (dalam Anggraini, 2017, hlm. 5) mengungkapkan minat atau interest dapat diartikan secara sederhana sebagai kegairahan dan keinginan besar tehadap segala hal. Minat baca dapat didefinisikan sebagai kecendrungan seseorang yang tinggi dan sifatnya sukarela atas dasar perasaan membutuhkan terhadap suatu sumber bacaan tertentu. Karena sifatnya yang timbul dari keinginan pribadi, tentu minat tidak bisa dipaksakan muncul oleh seseorang.

Minat tidak hadir begitu saja, tidak timbul juga semenjak anak dilahirkan namun, minat berkembang seiring pengalaman belajar anak. Minat membaca akan tumbuh sejalan dengan perkembangan anak yang sedini mungkin dikenalkan pada bahan bacaan. Umumnya, seorang anak yang biasa dibacakan buku cerita akan lebih mencintai buku saat dewasanya nanti (dalam Susanti, 2017, hlm. 155).

Hurlock (1976, hlm. 116) dalam bukunya mengemukakan bahwa perkembangan minat anak dilatar belakangi oleh dua aspek, yakni aspek kognitif dan aspek afektif. Hal ini sejalan dengan apa yang dikemukakan oleh Bloom (1956, hlm. 7) bahwa afektif termasuk ke dalam tujuan yang menggambarkan perubahan dalam minat, sikap, dan nilai, dan pengembangan apresiasi dan penyesuaian yang memadai.

lstilah media kerap kali dikaitankan dengan kegiatan pembelajaran. Dalam kegiatan pembelajaran itu sendiri, media mengandung arti sebagai kombinasi barang atau sistem barang apapun yang digunakan untuk menyampaikan komunikasi atau stimulus pembelajaran lainnya kepada anak. Pada dasarnya, bukan media yang merancang atau merumuskan komunikasi, media, bagaimanapun itu hanya sebatas penyampai saja.

Penggunaan komik dalam kegiatan pembelajaran membuat proses belajar menjadi lebih menarik, menyenangkan dan tidak membosankan, sehingga membangkitkan ketertarikan dan minat anak (Puspitorini, dkk. 2014, hlm. 415).

Komik disinyalir dapat memfasilitasi seseorang untuk mampu membaca suatu bacaan lebih berat yang nantinya akan mengembangkan anak menjadi pembaca yang cakap (Krashen, dalam Graham. 2011. hlm. 93). Selain itu, Sujana dan Rivai (2002, hlm. 69) mengemukakan bahwa minat, pembendaharaan kata, dan keterampilan membaca dapat ditingkatkan dan dikembangkan melalui penggunaan media komik.

Komik papertoon hanyalah sebutan istilah yang digunakan penulis dalam 
menggambarkan media yang digunakan dalam penelitian ini. Meskipun demikian, komik papertoon tercipta dengan memadukan antara komik serta mengadopsi sifat dasar dari penggunaan poster. Mengacu dari pendapat yang dikemukakan oleh Mustikan (dalam Utari \& Saputra, 2016, hlm. 33), komik merupakan sebuah karya yang didalamnya mengandung unsur memadukan antara gambar dan bahasa.

Sedangkan Mc. Cloud (2001, hlm 1) mengatakan bahwa komik merupakan kesatuan gambar atau simbol yang tersusun dalam sebuah urutan hingga membentuk cerita utuh dan pembaca dapat menangkap suatu informasi lalu menanggapinya dengan estetis.

\section{Metode Penelitian}

Penelitian ini dilakukan di dua kelas berbeda namun dalam satu sekolahan, yakni di TK Perwari 1 kelas B1 dan B2. Kerena penelitian ini lebih berfokus terhadap pengembangan suatu media dalam menunjang keterlaksanaan pembelajaran, maka penelitian ini menggunakan pendekatan Design Based Research (DBR). Adapun tahap-tahap penelitian yang akan dilaksanakan oleh peneliti bersumber pada desain penelitian yang dikembangkan oleh Reeves (2008, hlm. 34). Prosesnya terbagi menjadi 4 tahapan, yang secara secara garis besar yakni, identifikasi dan analisis masalah, pengembangan prototype program, uji coba dan implementasi prototype program, dan refleksi untuk mendapatkan prinsip desain yang diharapkan dan mengatasi berbagai permasalahan yang muncul.

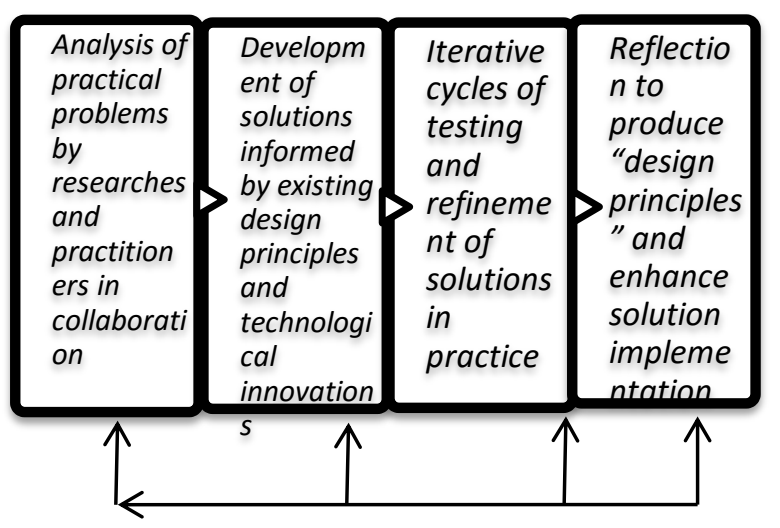

Gabar 2.1

Prosedur DBR Model Reeves
Teknik pengumpulan data menggunakan wawancara, expert judgment (validasi ahli), observasi, serta dokumentasi, dengan istrumen penelitian Kisi-kisi pedoman wawancara saat studi pendahuluan, kisi-kisi lembar pedoman wawancara guru setelah uji coba prototype, kisi-kisi lembar validasi ahli media, ahli materi, ahli pedagogik, serta Kisi-Kisi Instrumen Observasi Minat Membaca Anak Kelompok B. Sedangkan untuk teknik analisis data peneliti menggunakan pendekatan kualitatif yang mengacu pada pemapara Milles and Hubberman (dalam Sugiono, 2013, hlm. 246) analisis data kualitatif harus dilakukan hingga data yang diperoleh sudah jenuh. Namun, hal ini hanya akan terjadi apabila aktivitas dalam analisis dilakukan secara interaktif, diulang-ulang dan terusmenerus hingga tuntas.

\section{TEMUAN DAN PEMBAHASAN}

\section{A. Identifikasi Masalah oleh peneliti dan praktisi secara kolaboratif}

Pada tahap pertama, peneliti melakukan studi pendahuluan terlebih dahulu di TK perwari 1 untuk mengetahui permasalahan yang dapat peneliti kaji. Studi pendahuluan dilakukan dengan mengamati keadaan, baik di dalam ataupun di luar kegiatan pembelajaran. Pengamatan dilakukan selama masa Program Pengalaman Lapangan (PPL) serta pengamatan lebih mendalam selama 5 hari.

Pada dasarnya, mengajarkan membaca pada anak usia dini merupakan salah satu problematika yang kerap kali dihadapi oleh para guru di TK Perwari 1. Disatu sisi, tuntutan orang tua mengharapkan anakanaknya telah pandai membaca ketika anak memasuki sekolah dasar. Namun dilihat dari sisi lainnya, yakni dari segi psikologis, anak pada usia dini belumlah sampai tahap dimana anak harus diajarkan membaca apalagi sudah mampu membaca. Menurut pemaparan guru kelas, pada awal-awal pembelajaran, anak dengan mudah mau dan bersedia membaca. Namun seiring berjalannya waktu, anak mulai enggan dan perlahan tidak mau ketika diminta untuk membaca buku bacaan yang telah disediakan. Peneliti dapat menyimpulkan, selama ini, khusunya di TK Perwari 1, membaca tak pernah dikenalkan pada anak sebagai kegiatan menyenangkan.

Problematika sebenarnya adalah cara atau metode yang perlu digunakan guru dalam 
mengajarkan membaca pada anak. Tentu anak perlahan akan memberontak jika setiap hari yang ia temui hanyalah buku monoton berisi tulisan yang sama sekali tidak bisa ia nikmati. Hal yang tak kalah penting dari membaca itu sendiri adalah kemauan anak untuk membaca. Akan sangat sia-sia apabila anak terus diajarkan membaca ketika minat anak terhadap membaca saja sama sekali tidak bisa dibangkitkan (dalam Anissa, 2015, hlm. 7). Meskipun belajar membaca dan pencapaian keterampilan membaca anak sangat penting, guru tetap harus ingat untuk selalu menghadirkan suatu pengalaman membaca yang positif dan menyenangkan sehingga anak bisa menikmati bahan bacaan (dalam Moser \& Marisson, 1998, hlm. 234).Penumbuhan minat membaca dengan memanfaatkan media yang menarik dinilai mampu meningkatkan kemampuan membaca anak dikemudian hari. Berpedoman pada beberapa teori yang peneliti kaji, penggunaan media komik mampu meumbuhkan minat serta pembendarahaan bahasa pada anak. Maka ditetapkanlah media komik papertoon yang akan peneliti kembangkan guna menumbuhkan minat membaca pada anak usia dini khususnya pada anak kelompok B di Taman Kanak-kanak

B. Pengembangan prototype sebagai solusi yang didasaran pada patokan teori, Design principle yang ada dan desain teknologi

Komik papertoon, merupakan sebuah media yang peneliti kembangkan setelah peneliti mengidentifikasi permasalahan dan peninjauan dari segi teori. Media komik disinyalir dapat membangitkan minat, pembendarahaan kata, serta kemampuan anak dalam membaca (Sujana dan Rivai 2016. hlm. 23) hal inilah yang akhirnya menggugah peneliti untuk mengembangkan sebuah media komik yang penggunaannya beda dari yang lain. Selain dirancang dengan menyesuaikan karakteristik anak usia dini, peneliti juga mengembangkan komik papertoon dengan mempertimbangkan beberapa aspek baik itu dari segi penggambaran, pewarnaan, penggunaan bahasa, penggunaan bahan, konten materi, kompetensi dasar, serta tema semester dua yang ada di taman kanak-kanak.

Dari segi pembuatan, media komik papertoon dirancang dengan menggunakan beberapa alat digital yakni laptop dan USB pen tablet serta beberapa software yakni Microsoft Paint, CorelDRaw X7 dan
Microsoft Word. Secara garis besar pembuatan media komik papertoon dilakukan dengan beberapa tahap, yakni:

a. Tahap perancangan komik papertoon Dalam tahap ini terdapat beberapa langkah yang perlu dilakukan, diantaranya 1) Menentukan tema yang akan diuraikan dalam isi cerita yang didasarkan pada tema kelompok B taman kanak-kanak. Tema yang digunakan dalam papertoon ini terdiri dari tema negaraku dengan sub tema hari kemerdekaan, tema elektronik dengan sub tema alat komunikasi, dan terakhir tema alam semesta dengan sub tema bumi dan bencana alam

2) Merencanakan plot atau jalan cerita. Terbagi menjadi tiga bagian yaitu bagian permulaan, bagian tengah, dan bagian akhir yang berisi penutup cerita atau penyelesian dari konflik yang ditampilkan. Adapaun plot cerita dalam komik papertoon yang peneliti kembangkan mencakup: (1) Plot papertoon I sub tema Alat Elektron, Bagian awal menegaskan bahwa cerita akan mengarah kepada alat-alat elektronik yang ada di rumah, bagian tengah menunjukan alat-alat eloktronik yang biasa ada di rumah, dan bagian akhir menceritakan alat-alat eloktronik yang biasa ada di rumah beserta penggunaannya; (2) Plot papertoon II sub tema Hari Kemerdekaan pada bagian awal menerangkan tentang tanggal kemerdekaan negara Indonesia, bagian tengah lebih menceritakan pada kegiatan-kegiatan yang biasa dilakukan di hari kemerdekaan, dan bagian akhir menegaskan bahwa kegiatan yang dilakukan merupakan bentuk peringatan kemerdekaan Indonesia; (3) Plot papertoon III sub tema Alam semesta di bagian awal cerita lebih menerangkan bahwa bumi yang merupakan tempat tinggal kita, bagian tengah menerangkan bahwa isi cerita akan berfokus terhadap apa saja yang ada dibumi, dan bagian 
akhir cerita ditutup dengan penjelasan bahwa selain makhluk hidup, dibumi juga ada benda mati. (4) Plot papertoon IV sub tema Bencana alam pada bagian awal cerita berfokus pada Andi dan ibunya yang melihat beberapa orang tengah buang sampah sembarangan, bagian tengah menerangkan cerita saat hujan besar terjadi dan Andi melihat banjir disekitar rumahnya, dan bagian akhir cerita ditutup dengan penjelasan Andi bawa banjir salah satunya disebabkan karena banyak orang yang selalu buang sampah sembarangan dan Andi berjanji, dia tidak akan lagi melakukan hal tersebut.

3) Perencanaan latar cerita yang akan digunakan dalam setiap panel. latar cerita harus menegaskan tentang dimana tempat saat cerita berlangsung.

b. Tahap pembuatan komik papertoon Full digital, terdiri dari beberapa langkah, yakni:

a. Pembuatan sketsa awal berupa coretan-coretan dasar,

b. Pembuatan sketsa final,

c. Pewarnaan gambar

d. Finalisasi lay out berupa pembuatan balon teks dan menyatukan panelpanel, dan terakhir mencetak gambar.

c. Tahap penyelesaian komik papertoon, berupa menempelkan magnet di bagian belakang papertoon yang huruf-hurufnya dihilangkan, melapisi komik papertoon menggunakan karton, serta pembuatan huruf-huruf sebagai pelengkap.

Konten materi yang termuat dalam isi cerita komik papertoon lebih mengacu kepada tema semester dua kelomopk B taman kanakkanak, yakni tema alat komunikasi dengan sub tema alat komunikasi elektronik; tema negaraku dengan sub tema hari kemerdekaan; alam semesta dengan sub tema bumiku dan bencana alam. Konten cerita yang mengacu pada tema ini sengaja dilakukan agar pengetahuan anak terhadap hal-hal yang bersangkutan dengan tema pun dapat terasah.
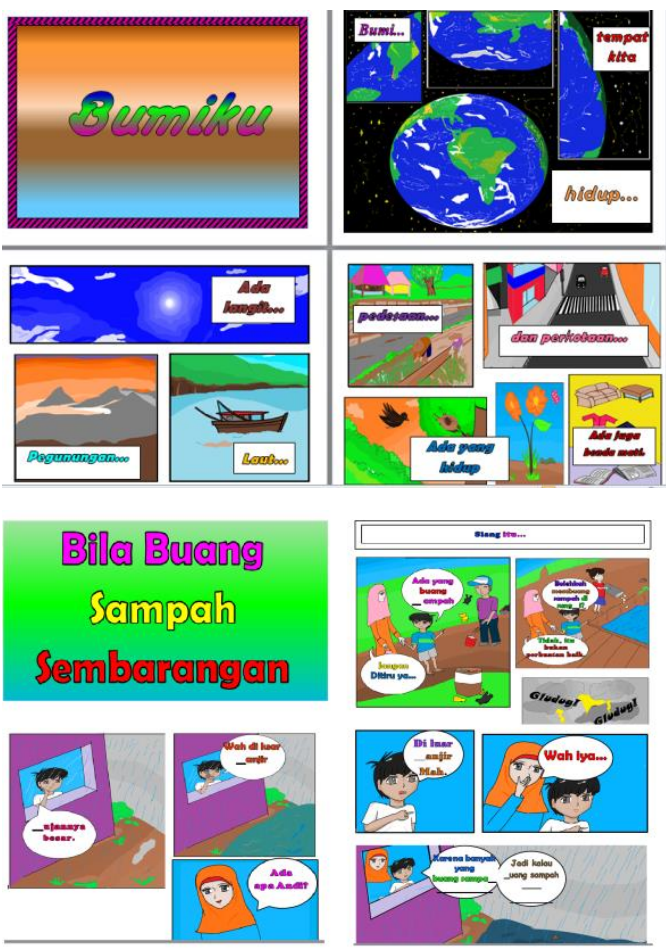

Gambar 3.1

Tampilan Akhir Komik Papertoon I dan II

Agar penggunaan media komik papertoon ini berjalan dengan efektif dan menimbulkan hasil yang diharapkan, ada beberapa hal yang perlu guru perhatikan dalam pelaksanaannya. Adapun prosedur penggunaan komik papertoon akan dijabarkan dalam uraian berikut:

a. Usahakan guru telah membaca dan memahami prosedur penggunaan serta keseluruhan dari media komik papertoon, baik itu isi cerita papertoon, kompetensi inti, kompetensi dasar, ataupun indikator dari pemanfaatan media ini.

b. Penggunaan media komik papertoon dapat guru terapkan dalam inti ataupun penutup pembelajaran. Dengan catatan, media komik papertoon sudah dipajang bahkan sebelum anak-anak datang ke sekolah.

c. Pemajangan media komik papertoon haruslah di tempat yang mudah dilihat dan sering dilewati anak.

d. Saat guru hendak menceritakan media komik papertoon, usahakan papertoon tetap tergantung di dinding.

e. Sebelum guru bercerita, bertanyalah terlebih dahulu pada anak. Siapa yang ingin mencoba untuk membacakan isi cerita papertoon. 
f. Stimulus anak agar anak mau menyentuh, meraba, ataupun membaca kata-kata yang sekiranya diketahui anak.

g. Stimulus anak untuk menebak apa yang tergambarkan dalam komik papertoon.

h. Setiap selesai membacakan panel, berkomunikasilah dengan anak, baik itu mengajak anak memahami maksud dari isi cerita, menanyakan kembali apa yang telah diceritakan ataupun pendapat anak tentang gambar yang ditampilkan.

i. Setelah selesai menceritakan keseluruhan isi komik papertoon, stimulus anak agar anak mau membacakan kembali komik papertoon.

j. Apabila waktu tersisa banyak dan anak masih ingin guru bercerita, kembalilah menceritakan isi papertoon.

k. Biarkan anak berimajinasi sesukanya ketika anak mau membacakan kembali isi cerita.

1. Biarkan anak mengemukakan pendapatnya tentang isi cerita ataupun media papertoon.

m. Bukan kepandaian anak dalam membaca yang menjadi fokus utama, namun keantusiasan anak dalam mengikuti, merespon dan mau membaca papertoonlah yang diharapkan muncul.

C. Proses validasi dan implementasi media komik papertoon untuk menumbuhkan minat membaca pada anak kelompok B di Taman Kanak-Kanak

Tahap selanjutnya yang dilakukan peneliti adalah melakukan validasi kelayakan media kepada beberapa ahli yakni ahli media, ahli materi, dan ahi pedagogik. Hasil dari validasi yang dilakukan ahli menjadi bahan perbaikan produk.

Setelah produk melakukan beberapa perbaikan sesuai masukan dan validator menyetujui serta menganggap media yang dikembangkan peneliti telah sesuai standar penilaian, tahap selanjutnya yang peneliti lakukan yakni menerapkan atau melakukan uji coba media komik papertoon dalam kegiatan pembelajaran.

Uji coba pertama dilakukan di kelas B2 dan uji coba kedua dilakukan di kelas B1. Dalam ujicoba pertama peneliti bertindak sebagai observer serta guru dalam mengimplementasikan komik papertoon selama kegiatan pembelajaran. Melihat dari respon awal yang ditunjukan anak, media komik papertoon mendapat perhatian anak yang kurang memuaskan. Kesan awal anak terhadap komik papertoon dinilai belum mencapai hasil yang diharapkan dan apabila dipersentasekan, keseluruhan aspek minat membaca yang bisa anak-anak tampilkan hanya mencapai 74,1\%. Meskipun belum terlalu memusakan, pencapaian hasil ini sudah cukup memenuhi keriteria penilaian yang diharapkan.

Setelah uji coba pertama dilakukan, peneliti kembali merancang komik papertoon untuk memperbaiki segala kekurangan dan kekeliruan dengan bercermin pada uji coba pertama serta masukan dari validator dan guru. Perbaikan dilakukan dengan memangkas kata-kata yang dinilai terlalu kompleks dan panjang utntuk anak usia dini, pewarnaan yang kurang menarik, penghilangan beberapa huruf dan kata dalam balon teks, bahan yang dijadikan alas komik papertoon, serta beberapa perbaikan lainnya.

Peneliti kembali melakukan uji coba dengan mengambil kelas yang berbeda. Selama kegiatan pembelajaran berlangsung, penggunaan media komik papertoon mendapat penerimaan dan respon yang cukup memuaskan. Rasa tertarik anak mulai tergugah ketika media komik papertoon dihadirkan dalam proses pembelajaran. Dengan antusias, anak-anak meampilkan prilaku yang diharapkan dan terlibat secara langsung dalam kegiatan bercerita yang dilakukan peneliti. Secara garis besar, setelah dilakukan beberapa revisi, aspek minat membaca yang ditampilan anak saat media komik papertoon diimplementasikan menunjukan pencapaian yang jauh lebih baik dari uji coba pertama yakni sebanyak 3,3 dan apabila dipersenkan menjadi 82,6\%. .

\section{Refleksi Media Komik Papertoon dalam Menumbuhkan Minat Membaca pada Anak Kelompok B di Taman Kanak-Kanak}

Setelah melakukan beberapa tahapan secara beruntun, dimulai dari perancangan, validasi kelayakan oleh tim ahli, uji coba produk, perbaikan sebanyak dua kali, serta proses revisi, penelitian yang dilakukan olah peneliti menghasilkan sebuah produk akhir 
berupa komik papertoon yang dikembangkan guna menumbuhkan minat membaca pada anak kelompok B di taman kanak-kanak. Konten materi yang termuat dalam isi cerita lebih mengacu terhadap tema semester dua yang ada di taman kanak-kanak. Selain itu, materi juga disesuaikan dengan kompetensi dasar anak kelompok b taman kanak-kanak berupa: Mengenal benda-benda disekitarnya (nama, warna, bentuk, ukuran, pola, sifat, suara, tekstur, dan fungsi-fungsi lainnya), Mengenal linkungan alam (hewan, tanaman, cuaca, tanah, air, batu-natuan, dll, Mengenal keaksaraan awal melalui bermain.

Penggunakan media dilakukan dengan memajang atau menempelkan komik papertoon di depan kelas atau di tempat yang mudah dan sering dilewati anak. Huruf awal di beberapa kata dalam balon teks sengaja dihilangkan. Hal ini dilakukan untuk meningkatkan kemampan keaksaraan anak. sehingga nantinya anak mampu menempelkan kata yang hilang tersebut. Pemajangan komik papertoon ini disesuikan dengan tema yang sedang berlangsung.

\section{SIMPULAN}

Ada beberapa kesimpulan yang dapat ditarik dari hasil penelitian yang telah dilakukan peneliti dalam mengembangkan media komik papertoon ini, diantaranya sebagai berikut:

a. Penggunaan media pembelajaran khususnya dalam meningkatkan kemampuan membaca pada anak kelompok B di TK Perwari 1 terbilang sangat minim dan bahkan, jarang sekali digunakan dalam proses pembelajaran. Buku bacaan yang hampir setiap hari digunakan anak, nyatanya lambat laun malah memberikan kejenuhan pada diri anak hingga beberapa dari mereka mulai enggan dan tidak mau ketika diajak untuk membaca. Tak jarang, guru harus memberikan ancaman terlebih dahulu pada anak agar anak bersedia membaca. Membaca tak pernah diajarkan sebagai kegiatan menyenangkan yang jauh dari kata membosankan. Sehingga bukan hal mengherankan apabila anak bahkan menunjukkan sikap tidak suka dalam kegiatan membaca dan bahkan menolak kegiatan pembelajaran yang didalamnya lebih menonjolkan membaca.

b. Permasalahan yang peneliti kaji menghasilkan sebuah solusi, dalam hal ini, yang harus diperhatikan terlebih dahulu saat mengajarkan anak membaca adalah menumbuhkan rasa cinta dan minat anak terhadap sumber bacaan. Sehingga solusi yang disajika peneliti yakni, pengembangan sebuah media yang penggunaannya dapat menstimulus rasa cinta dan keinginan anak dalam membaca, berupa komik papertoon. Setelah proses perancangan, peneliti kemudian melakukan validasi produk kepada para ahli, baik itu ahli bahasa, ahli media, dan juga ahli pedagogik. Dari hasil validasi, diperlukan adanya beberapa perbaikan agar tampilan komik papertoon layak untuk diujicobakan.

c. Tahap uji coba dilakukan sebanyak dua kali. Pada tahap pertama, uji coba dilakukan di kelas B2 dengan subjek sebanyak 15 orang anak. Hasil uji coba menunjukan respon yang cukup baik dari guru kelas dan guru pendamping. Perilaku yang ditunjukan anak pun cukup baik meski belum mencapai hasil yang diharapkan. Sehingga dilakukanlah perbaikan terhadap tampilan serta peroses penggunaan komik papertoon. Pada uji coba kedua, respon yang ditunjukan guru sangat baik, begitupun halnya dengan perilaku yang dutampilkan anak. Sudah sesuai dengan standar penilaian dan tahap perlembangan yang diharapkan.

d. Setelah melakukan serangkaian tahapan secara beruntun serta melakukan revisi berulang, akhirnya dihasilkanlah sebuah produk berupa media komik papertoon unuk menumbuhkan minat baca pada anak kelompok B di Taman kanak-kanak. Produk berbahan dasar kertas dengan ukuran $75 \mathrm{~cm} \times 35 \mathrm{~cm}$ yang didalamnya tersusun berbagai gambar hingga membentuk sebuah cerita. Konten cerita 
dalam komik papertoon mengacu pada tema semester dua yang ada di taman kanak-kanak. Untuk penggunaannya, komik papertoon dipajang di diding yang masih berada dalam jangkauan anak.

\section{SARAN}

1. Bagi pengguna media komik papertoon, agar media tahan lama dan tidak mudah rusak, sebaiknya setelah digunakan, media disimpan ditempat yang cukup aman dan tidak ditumpuk benda-benda berat. Penggunaan setiap komik papertoon hanya bisa diterapkan dalam satu tema. Meski demikian pemajangan bisa dilakukan kapanpun dan dimanapun.

2. Penggunaan media komik papertoon hanya akan memberikan hasil yang signifikan ketika guru pun terlibat secara langsung dalam proses penggunaan. Berceritalah secara aktraktif agar anak antusias dan selalu ingatkan anak pada media komik papertoon.

3. Banyaknya keterbatasan dari penelitian ini memerukan perhatian dan penelitian yang lebih lanjut. Perlu adanya kajian lebih mendalam tentang menumbuhkan minat membaca pada anak serta keefektifan penggunaan dari komik itu sendiri.

\section{DAFTAR PUSTAKA}

Anggraini, N. (2017). Peran Orang Tua Dalam Meningkatkan Minat Baca Anak TK di Kecamatan Pulung (Skripsi). Sekolah Sarjana, Universitas Airlangga, Surabaya

Anissa, R.R.S. (2015). Meningkatkan Minat Baca Pada Anak Menggunaka Metode Bercerita pada Anak Kelompok B Di KB/TK Islam Bintang Kecil Gajahan Colomadu Karanganyar. Surakarta: Universitas Muhammadiyah SurakartaBloom

Bloom, B.S. dkk. (1956). Taxonomy of Educational Objectives the Classification of Educational Goals. London: Longman Group Ltd.Graham Hurlock, B, Elizabeth. (1978). Perkembangan Anak jilid 2. Jakarta: Erlangga

Lee, Y. B. (2011). Assessing Book Knowledge Through Independent Reading in the Earliest Years: Practical Strategies and Implications for Teachers. Early Childhood Educ J, 39,
285 - 290. doi: 10.1007/s10643-0110464-y

McCloud, S. (2001). Understanding Comic. Jakarta: Kepustakaan Populer Gramedia.

McVicker, C. J. (2007). Comic Strips as a Text Structure for Learning to Read. The Reading Teacher, 1, 85-88. doi:10.1598/RT.61.1.9

Puspitorini, R. Dkk. (2014). Penggunaan Media Komik dalam Pembelajaran IPA Untuk Meningkatkan Motivasi dan Hreeves

Reeves, T.C. \& Amiel, T. (2008). Design based research and educational technology: rethinking technology and the research agenda. Journal Education Technology \& Society, 11(4), hlm. 2940.Sugiono

Sudjaja, N. \& Rivai, A. (2002). Media Pengajaran. Bandung: Sinar Baru Algesindo

Untari, M.F.A., \& Saputra, A.A. (2016). Keefektifan Media Komik Terhadap Kemampuan Membaca Pemahaman pada Siswa Kelas IV SD. Mimbar Sekolah Dasar, 3, 29 - 39. doi: 10.17509/mimbar-sd.v3i1.2354

Waluyanto, H.D. (2015). Komik Sebagai Media Komunikasi Visual Pembelajaran. Nirmana, 7(1), 45 - 55.

Widianto, S. (2017, 17 Maret). "Soal Minat Baca, Indonesia Peringkat 60 dari 61 Negara". Pikiran Rakyat 